\title{
Isolation and Characterization of Shewanella alga from Human Clinical Specimens and Emendation of the Description of $S$. alga Simidu et al., 1990, 335
}

\author{
HATSUMI NOZUE ${ }^{1}{ }^{1} *{ }^{*}$ TETSUYA HAYASHI,${ }^{1}$ YASUHIRO HASHIMOTO ${ }^{2}$ TAKAYUKI EZAKI, ${ }^{2}$ \\ KOJI HAMASAKI, ${ }^{3}$ KOUICHI OHWADA, ${ }^{3}$ AND YOSHIRO TERAWAKI ${ }^{1}$ \\ Department of Bacteriology, Shinshu University School of Medicine, Asahi 3-1-1, Matsumoto 390, ${ }^{1}$ \\ Department of Microbiology, Gifu University School of Medicine, 40 Tsukasamachi, Gifu 5002, ${ }^{2}$ and \\ Ocean Research Institute, University of Tokyo, Minamidai 1-15-1, Nakanoku, Tokyo 164, Japan
}

\begin{abstract}
Genetic and phenotypic studies on the strains biochemically identified as Shewanella putrefaciens, which had a G+C content ranging from 52 to 54 mol\% were conducted. The moles percent $G+C$ of the type strain of $S$. putrefaciens is 46. Surprisingly, DNA homology experiments revealed that all these strains are genetically related to Shewanella alga (which was reported to produce tetrodotoxin), not to the type strain of $S$. putrefaciens. In this study, we reidentified clinical strains of $S$. putrefaciens which have a high range of moles percent $G+C$, as does $S$. alga. We also characterized the reidentified strains and found that the original description of S. alga (U. Simidu, K. Kita-Tsukamoto, T. Yasumoto, and M. Yotsu, Int. J. Syst. Bacteriol. $40: 331-336,1990$ ) is insufficient to identify this strain. An emended description of $S$. alga is given.
\end{abstract}

The organism now called Shewanella putrefaciens was first described in 1931 and classified as a member of the genus Achromobacter (4). In 1941, it was transferred to the genus Pseudomonas (16) on the basis of morphology. In 1972, it was transferred to the genus Alteromonas (1) on the basis of $\mathrm{G}+\mathrm{C}$ content. Finally, in 1985, it was transferred to a new genus, Shewanella, on the basis of comparative $5 \mathrm{~S}$ rRNA sequences (17). The type species of Shewanella is $S$. putrefaciens (17).

Many of the strains classified as $S$. putrefaciens were isolated from diverse sources, including environmental sources, such as spoilage flora of foods $(12,14,18,28)$, oil fields (24), and the ocean $(1,13)$, and diverse clinical sources, such as patients with otitis, bronchitis, pneumonia, and urinary tract infections $(3,6,9,14,15,21,22,29)$. However, the collected strains were heterogeneous and there were differences between environmental and clinical isolates $(9,14,20,21,23,24,28)$. Owen et al. (20) divided the 10 environmental strains and 16 clinical strains into four groups. Group IV consisted of nine clinical strains. The moles percent $\mathrm{G}+\mathrm{C}$ value for group IV (52.6) was clearly higher than those for the other three groups (43.9 to 46.9). All four groups retained the species identification of $S$. putrefaciens, despite the obvious heterogeneity and moles percent $G+C$ values ranging from 43 to 55 (2).

Recently, we noticed that most strains isolated from human clinical specimens and identified as $S$. putrefaciens showed beta-hemolysis on sheep blood agar. However, environmental strains were nonhemolytic. These hemolytic strains had 52 to $54 \mathrm{~mol} \% \mathrm{G}+\mathrm{C}$. Although the hemolytic strains are biochemically identified as $S$. putrefaciens according to the description in the Manual of Clinical Microbiology (7), they exhibited high levels of DNA homology with the type strain of $S$. alga. In this study, we present evidence that these clinical strains of $S$. putrefaciens should be identified as $S$. alg $a$ and emend the description of $S$. alga

\footnotetext{
* Corresponding author.

† Present address: Center for Molecular Biology, Wayne State University, Detroit, MI 48202.
}

on the basis of the physiological characterization of 35 additional strains.

$S$. alga is known to be a tetrodotoxin (TTX)-producing bacterium $(25,26)$. Production of TTX by some newly reidentified strains was examined. This is the first report of TTX production by strains isolated from human clinical specimens.

\section{MATERIALS AND METHODS}

Strains used and isolation technique. The type strain of $S$. putrefaciens IAM 12079 (= ATCC $8071^{\mathrm{T}}$ [T = type strain]) and three IAM strains, previously registered in $S$. putrefaciens culture collections with accession numbers IAM 13595 (= NCTC 10737), IAM 13614 (= NCTC 10738), and IAM 13615 (= NCTC 10762), were supplied by the Microbial and Microalgal Research Center, Institute of Applied Microbiology, University of Tokyo. The type strain of $S$. alga $\left(\mathrm{OK}-1=\mathrm{IAM} 14159^{\mathrm{T}}\right)$ was supplied by Ocean Research Institute, University of Tokyo. Forty clinical strains of $S$. putrefaciens isolated from different human clinical specimens were provided by several researchers in Japan (Table $1)$. We also isolated 32 strains of $S$. putrefaciens from pond water, sewage, foods, soil, and the skin of animals and used them to find physiological traits distinguishing $S$. putrefaciens from $S$. alga. Six of these strains were used for DNA-DNA hybridization experiments.

The primary step of isolation was performed in an aerobic environment by selective growth in peptone solution containing $1 \%$ peptone (Difco Laboratories, Detroit, Mich.), $1 \%$ $\mathrm{NaCl}$, and $0.1 \%$ bile salts (Difco). Nonfermentative, hydrogen sulfide-producing colonies were selected on deoxycholate-hydrogen sulfide-lactose (DHL) agar (Eiken Chemical Co., Ltd., Tokyo, Japan). Isolates were finally identified as $S$. putrefaciens by additional biochemical tests described in the Manual of Clinical Microbiology (7).

Physiological tests. Physiological tests were performed by the methods described in the Manual of Clinical Microbiol$o g y(7)$, except for those tests described below. Lecithinase and lipase activities were detected by the methods of Stenstrom et al. (28), and $\beta$-galactosidase was detected as de- 
TABLE 1. Characteristics of strains used ${ }^{a}$

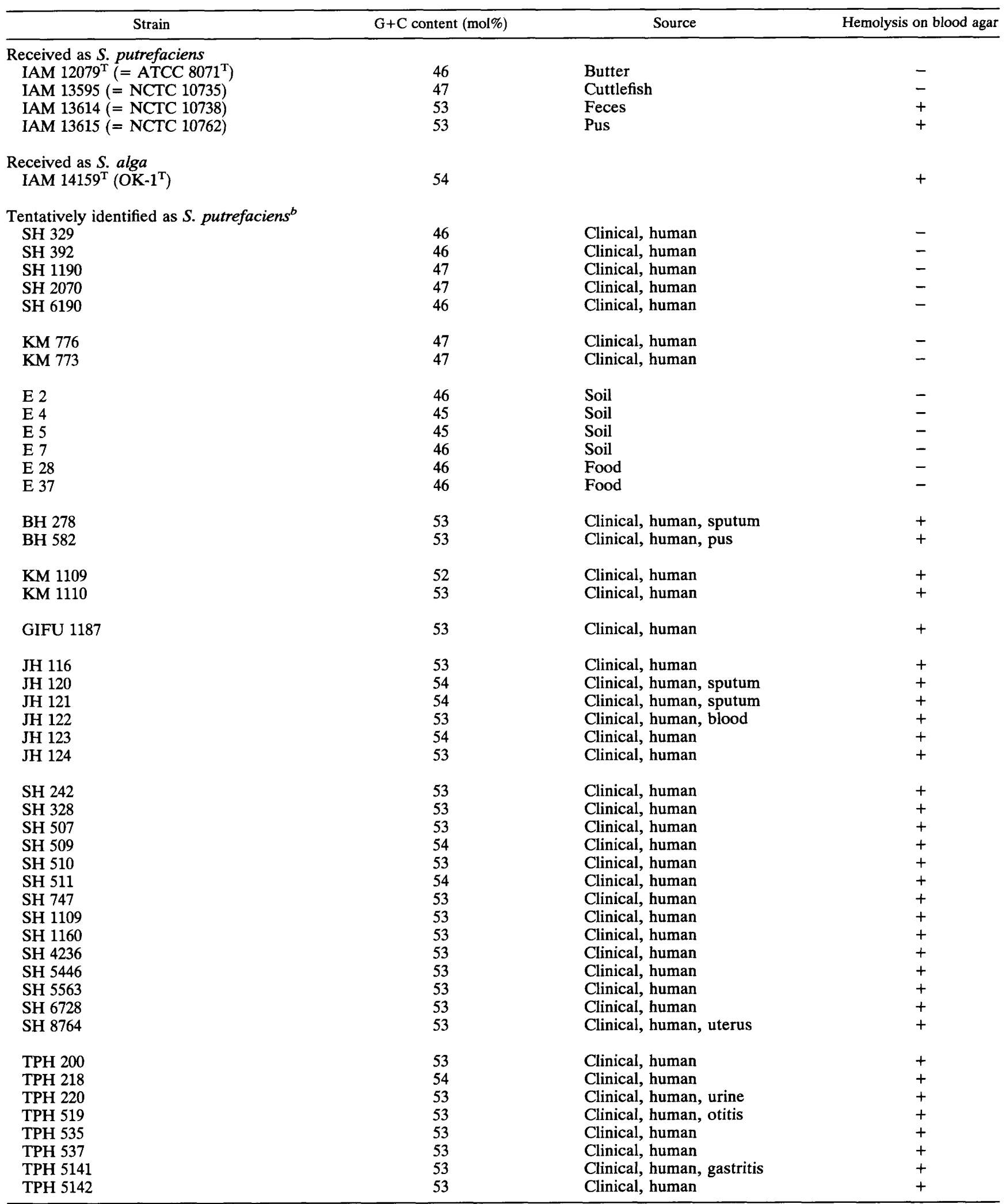

a All clinical, soil, and food strains were tentatively identified as $S$. putrefaciens by conventional biochemical tests.

b Strain designations beginning with $\mathrm{BH}, \mathrm{KM}, \mathrm{GIFU}, \mathrm{JH}, \mathrm{SH}$, and TPH were kindly provided by different hospitals in Japan. Strain designations beginning with E were isolated by us (see Materials and Methods). 
scribed by Smibert and Krieg (27). The medium developed by Wood and Baird (30) was used to determine reduction of trimethylamine oxide. Trimethylamine production after 2 days of incubation at $30^{\circ} \mathrm{C}$ was examined by the method of Laycock and Reiger (12). Growth temperatures were tested on nutrient agar plates (Difco) supplemented with $1.5 \% \mathrm{NaCl}$ for 7 days at 37 or $42^{\circ} \mathrm{C}$ and for 14 days at $4^{\circ} \mathrm{C}$. Tolerance to $\mathrm{NaCl}$ was determined visually after $48 \mathrm{~h}$ of vigorous shaking in nutrient broth (Difco) supplemented with $6 \% \mathrm{NaCl}$ at $30^{\circ} \mathrm{C}$. Hemolysis was determined from sheep blood agar plates (Eiken Chemical Co., Ltd.) incubated at 30 or $37^{\circ} \mathrm{C}$ for 2 days. Flagellar staining was performed as described by Heimbrook et al. (8).

Determination of $\mathbf{G}+\mathbf{C}$ content of DNA. Ten micrograms of the denatured DNA was hydrolyzed with P1 nuclease (50 $\mu \mathrm{g} / \mathrm{ml}$ in $50 \mathrm{mM}$ acetate buffer containing $0.1 \mathrm{mM} \mathrm{ZnCl}_{2}[\mathrm{pH}$ 5.3]; Yamasa Shoyu Co., Ltd., Chiba, Japan) for $2 \mathrm{~h}$ at $50^{\circ} \mathrm{C}$. Then, $2.4 \times 10^{-2} \mathrm{U}$ of alkaline phosphatase (Takara Shuzo Co., Ltd., Tokyo, Japan) was added, and the mixture was incubated at $37^{\circ} \mathrm{C}$ for $1 \mathrm{~h}$. Separation and quantification of nucleosides were performed with high-performance liquid chromatography (HPLC) system LC-6A (Shimadzu Co., Ltd., Kyoto, Japan) and a Cosmosil $5 \mathrm{C}_{18}$ column (Nakarai Tesque Co., Ltd., Kyoto, Japan). The nucleosides were eluted with a solvent system of $0.2 \mathrm{M} \mathrm{NH}_{4} \mathrm{H}_{2} \mathrm{PO}_{4}$-acetonitrile (20:1 [vol/vol]).

DNA-DNA homology experiment. The method of fluorometric hybridization using biotin-labelled DNA was described previously (5). DNA-DNA hybridization was carried out in $50 \%$ formamide solution at $37^{\circ} \mathrm{C}$ for $180 \mathrm{~min}$.

Analysis of TTX and its derivatives. Each strain was cultured in $400 \mathrm{ml}$ of $\mathrm{L}$ medium, which contains $0.5 \%$ polypeptone (Nihon Pharmaceutical Co., Ltd.), $0.1 \%$ yeast extract (Difco Laboratories), $1 \% \mathrm{NaCl}, 0.2 \% \mathrm{KCl}$, and $0.4 \%$ $\mathrm{MgSO}_{4} \cdot 7 \mathrm{H}_{2} \mathrm{O}$. After incubation for $18 \mathrm{~h}$ at $20^{\circ} \mathrm{C}$, cells were harvested by centrifugation at $16,000 \times g$, and then the toxins were extracted from cells and culture medium.

After the cells were washed with $0.3 \mathrm{M} \mathrm{NaCl}$ solution, they were suspended in $0.1 \%$ acetic acid, subsequently ultrasonicated, and boiled for $20 \mathrm{~min}$. The extract was centrifuged at $25,000 \times g$ for $20 \mathrm{~min}$, and then the supernatant was purified using a SEP-PAK $\mathrm{C}_{18}$ cartridge (Waters Associates). The eluate was evaporated to dryness, and the residue was dissolved in a small amount of distilled water.

The culture medium was acidified to $\mathrm{pH} 3.5$ with acetic acid, boiled for $20 \mathrm{~min}$, and evaporated to dryness. The residue was extracted three times with methanol containing $1 \%$ acetic acid. After evaporation to dryness, the residue was dissolved in distilled water. The solution was further purified by passage through a charcoal column and a SEPPAK $\mathrm{C}_{18}$ cartridge. The eluate was evaporated to dryness, and the residue was dissolved in a small amount of distilled water.

Ion-paired reverse-phase HPLC was used to separate and detect TTX and its derivatives in the extracts (31). A JUSCO Tri Roter-VI chromatograph (Japan Spectroscopic Co., Ltd., Tokyo, Japan) with a Senshu Pak ODS-3251-D column (Senshu Scientific Co.) was used for HPLC. For detecting fluorescence, the excitation and emission wavelengths were set at 365 and $510 \mathrm{~nm}$, respectively, on a Hitachi F1000 fluorescence spectrophotometer. The tissue culture bioassay (11) was performed for the determination and quantitative measurement of sodium channel-blocking toxin in the samples.

\section{RESULTS}

DNA base composition. The moles percent $G+C$ values of the strains examined in this study are shown in Table 1 . The $\mathrm{G}+\mathrm{C}$ content of the $S$. putrefaciens type strain (IAM 12079 ${ }^{\mathrm{T}}$ ) was $46 \mathrm{~mol} \%$. The moles percent G+C of IAM 13614, IAM 13615 , and $\beta$-hemolytic clinical strains (which were biochemically identified as $S$. putrefaciens) were distinctly higher and ranged from 52 to 54 . The results indicate that these clinical strains and two IAM strains are clearly different from IAM $12079^{\mathrm{T}}$ but are quite similar to $S$. alga with regard to their $\mathrm{G}+\mathrm{C}$ content, because the $\mathrm{G}+\mathrm{C}$ content of the $S$. alga type strain (IAM $14159^{\mathrm{T}}$ ) was reported to be 54 mol\% (26).

The $\mathrm{G}+\mathrm{C}$ content of the nonhemolytic strains, including IAM $12079^{\mathrm{T}}$, IAM 13595, and some of the clinical strains and newly isolated environmental strains all ranged from 45 to 48 mol\%.

DNA-DNA homology. DNA relatedness between $S$. alga IAM $14159^{\mathrm{T}}$ and $S$. putrefaciens strains was examined (Table 2). Labelled DNAs from IAM $12079^{\mathrm{T}}$, SH 329, and IAM 13595 were used as DNA probes for $S$. putrefaciens strains that have a low moles percent $\mathrm{G}+\mathrm{C}$. Labelled DNAs from IAM $14159^{\mathrm{T}}$ and IAM 13615 were used as DNA probes for $S$. alga and $S$. putrefaciens strains that have a high moles percent $\mathrm{G}+\mathrm{C}$. A high level of homology was found between IAM 13615 and IAM $14159^{\mathrm{T}}$ (89 and $105 \%$ ), but no significant homology was found between IAM 13615 and any $S$. putrefaciens strain that has a low moles percent G+C. DNA homology values between IAM 13615 and IAM $12079^{\mathrm{T}}$ were 12 and $9 \%$. The results mean that IAM 13615 belongs to the $S$. alga species and not to the $S$. putrefaciens species.

DNA-DNA hybridization experiments using clinical strains of $S$. putrefaciens which have a high moles percent $\mathrm{G}+\mathrm{C}$ and the IAM 13615 DNA probe resulted in high DNA homology values ranging from 70 to $100 \%$ (Table 2). These results indicate that all of the clinical strains belong to the same species as IAM 13615; that is, they belong to $S$. alga. $S$. putrefaciens strains that have a low moles percent $\mathrm{G}+\mathrm{C}$ were divided into three DNA homology groups, as shown by Owen et al. (20).

Physiological characteristics of $S$. alga strains. The physiological tests of $S$. alga strains, including IAM $14159^{\mathrm{T}}$, revealed several characteristics of $S$. alga that have not yet been described (Table 3), which are summarized as follows. (i) Growth occurred at 37 and $42^{\circ} \mathrm{C}$, but not at $4^{\circ} \mathrm{C}$. (ii) Growth occurred in nutrient broth containing $6 \% \mathrm{NaCl}$ and on Salmonella-Shigella (SS) agar. (iii) All strains produced hydrogen sulfide. The reactions were very strong. The color of the Kligler iron agar slant changed to black within several hours of incubation at $37^{\circ} \mathrm{C}$. (iv) The strains produced ornithine decarboxylase and lecithinase and reduced trimethylamine oxide to trimethylamine. (v) The strains exhibited clear hemolysis on sheep blood agar. Although hemolysis was obscure on the first day of incubation, it became clear on the second day at $37^{\circ} \mathrm{C}$. (vi) Acids were oxidatively produced from D-ribose $(100 \%)$ and D-glucose $(60 \%)$ in the Hugh and Leifson O-F medium after 4 to 12 days of incubation. Acids were not produced from D-arabinose, L-arabinose, D-mannose, mannitol, iso-inositol, L-rhamnose, D-xylose, sucrose, maltose, and D-lactose after 14 days of incubation.

Production of TTX and its derivatives. Production of TTX by four clinical strains which were newly reidentified as $S$. alga, IAM 13615, JH 122, TPH 519, and SH 8764, were examined (Table 4). A clear single peak corresponding to 4-epi-tetrodotoxin (4-epi-TTX) was detected in each cell 
TABLE 2. DNA homology values of the strains tentatively identified as $S$. putrefaciens $\boldsymbol{p}^{a}$

\begin{tabular}{|c|c|c|c|c|c|c|}
\hline \multirow{2}{*}{ Strain } & \multirow{2}{*}{$\mathrm{Mol} \% \mathrm{G}+\mathrm{C}$} & \multicolumn{5}{|c|}{$\%$ DNA homology with the following probe: } \\
\hline & & IAM $12079^{\mathrm{T}}$ & SH 329 & IAM 13595 & IAM $14159^{\mathrm{T}}$ & IAM 13615 \\
\hline IAM $12079^{\mathrm{T}}$ & 46 & 100 & 53 & 54 & 0 & 12 \\
\hline E 5 & 45 & 95 & 50 & 56 & $\mathrm{ND}^{b}$ & ND \\
\hline SH 329 & 46 & 43 & 100 & 40 & 14 & 10 \\
\hline SH 392 & 46 & 53 & 102 & 46 & ND & ND \\
\hline KM 773 & 47 & 36 & 99 & 28 & ND & ND \\
\hline KM 776 & 47 & 42 & 101 & 42 & ND & ND \\
\hline E 4 & 47 & 37 & 96 & 42 & ND & ND \\
\hline IAM 13595 & 47 & 28 & 23 & 100 & 10 & 3 \\
\hline E 2 & 46 & 42 & 24 & 76 & ND & ND \\
\hline E 7 & 46 & 50 & 42 & 77 & ND & ND \\
\hline E 28 & 46 & 55 & 36 & 96 & ND & ND \\
\hline E 37 & 46 & 52 & 43 & 93 & ND & ND \\
\hline IAM $14159^{T}$ & 54 & 8 & 5 & 0 & 100 & 89 \\
\hline IAM 13615 & 53 & 9 & 2 & 5 & 105 & 100 \\
\hline IAM 13614 & 53 & ND & ND & ND & ND & 83 \\
\hline BH 278 & 53 & ND & ND & ND & ND & 106 \\
\hline BH 582 & 53 & ND & ND & ND & ND & 101 \\
\hline KM 1109 & 52 & ND & ND & ND & ND & 86 \\
\hline KM 1110 & 53 & ND & ND & ND & ND & 81 \\
\hline GIFU 1187 & 53 & ND & ND & ND & ND & 99 \\
\hline JH 120 & 54 & ND & ND & ND & ND & 77 \\
\hline JH 121 & 54 & ND & ND & ND & ND & 80 \\
\hline JH 122 & 53 & ND & ND & ND & ND & 82 \\
\hline JH 123 & 54 & ND & ND & ND & ND & 94 \\
\hline JH 124 & 53 & ND & ND & ND & ND & 79 \\
\hline SH 242 & 53 & ND & ND & ND & ND & 104 \\
\hline SH 328 & 53 & ND & ND & ND & ND & 70 \\
\hline SH 507 & 53 & ND & ND & ND & ND & 82 \\
\hline SH 509 & 54 & ND & ND & ND & ND & 88 \\
\hline SH 510 & 53 & ND & ND & ND & ND & 98 \\
\hline SH 511 & 54 & ND & ND & ND & ND & 91 \\
\hline SH 747 & 53 & ND & ND & ND & ND & 91 \\
\hline SH 1109 & 53 & ND & ND & ND & ND & 80 \\
\hline SH 1160 & 53 & ND & ND & ND & ND & 85 \\
\hline SH 4236 & 53 & ND & ND & ND & ND & 106 \\
\hline SH 5446 & 53 & ND & ND & ND & ND & 81. \\
\hline SH 5563 & 53 & ND & ND & ND & ND & 73 \\
\hline SH 6728 & 53 & ND & ND & ND & ND & 102 \\
\hline SH 8764 & 53 & ND & ND & ND & ND & 108 \\
\hline TPH 200 & 53 & ND & ND & ND & ND & 106 \\
\hline TPH 218 & 54 & ND & ND & ND & ND & 80 \\
\hline TPH 220 & 53 & ND & ND & ND & ND & 77 \\
\hline TPH 519 & 53 & ND & ND & ND & ND & 98 \\
\hline TPH 535 & 53 & ND & ND & ND & ND & 88 \\
\hline TPH 537 & 53 & ND & ND & ND & ND & 88 \\
\hline ТPH 5141 & 53 & ND & ND & ND & ND & 96 \\
\hline TPH 5142 & 53 & ND & ND & ND & ND & 89 \\
\hline
\end{tabular}

${ }^{a}$ IAM $12079\left(=\right.$ ATCC $\left.8071^{\mathrm{T}}\right)$ is the type strain of $S$. putrefaciens. IAM $14159\left(=\right.$ OK-1 $\left.1^{\mathrm{T}}\right)$ is the type strain of $S$. alga.

${ }^{b} \mathrm{ND}$, not determined. 
TABLE 3. Characteristics of $S$. alga

\begin{tabular}{|c|c|c|}
\hline Property & $\begin{array}{l}\text { \% Positive clinical } \\
\text { strains }\left(n=35^{a}\right)\end{array}$ & $\begin{array}{l}\text { Characteristic of } \\
S \text {. alga } \text { IAM } 14159^{\mathrm{T}}\end{array}$ \\
\hline Motility & 100 & + \\
\hline Flagella, polar monotrichous & 100 & + \\
\hline Pyoverdin & 0 & - \\
\hline Hydrogen sulfide & 100 & + \\
\hline Indophenol oxidase & 100 & + \\
\hline Trimethylamine oxide & 100 & + \\
\hline$\beta$-Galactosidase & 6 & - \\
\hline Arginine dehydrolase & 0 & - \\
\hline Lysine decarboxylase & 0 & - \\
\hline Ornithine decarboxylase & 100 & + \\
\hline Sodium citrate (Simmons) & 0 & - \\
\hline \multicolumn{3}{|l|}{ Hydrolysis of: } \\
\hline Urea & 0 & - \\
\hline Lecithin & 100 & + \\
\hline Lipid & 100 & + \\
\hline Gelatin & 100 & + \\
\hline DNA & 100 & + \\
\hline \multicolumn{3}{|l|}{ Acid in O-F medium from: } \\
\hline D-Glucose & $(60)^{b}$ & + \\
\hline D-Arabinose & 0 & - \\
\hline L-Arabinose & 0 & - \\
\hline D-Mannose & 0 & - \\
\hline Mannitol & 0 & - \\
\hline iso-Inositol & 0 & - \\
\hline L-Rhamnose & 0 & - \\
\hline D-Ribose & $(100)$ & + \\
\hline D-Xylose & 0 & - \\
\hline Sucrose & 0 & - \\
\hline Maltose & 0 & - \\
\hline D-Lactose & 0 & - \\
\hline \multicolumn{3}{|l|}{ Growth under condition: } \\
\hline SS agar & 88 & + \\
\hline $6.0 \% \mathrm{NaCl}$ & 100 & + \\
\hline $4^{\circ} \mathrm{C}$ & 0 & - \\
\hline $37^{\circ} \mathrm{C}$ & 100 & + \\
\hline $42^{\circ} \mathrm{C}$ & 97 & + \\
\hline Hemolysis on sheep blood agar & 100 & + \\
\hline
\end{tabular}

${ }^{a}$ Number of strains examined, including IAM 13614, IAM 13615, and 33 clinical strains.

${ }^{b}$ Parentheses indicate that the reaction was delayed.

extract (Fig. 1). TTX and anhydrotetrodotoxin (anh-TTX) were detected in culture medium, but, the peaks corresponding to these two compounds were very small and unclear. Additional experiments using tissue culture assay (Table 4) showed the presence of significant levels of sodium channelblocking toxin in both cells and culture medium for two strains (TPH 519 and SH 8764) or in either the cells or culture medium for two strains (IAM 13615 and JH 122).

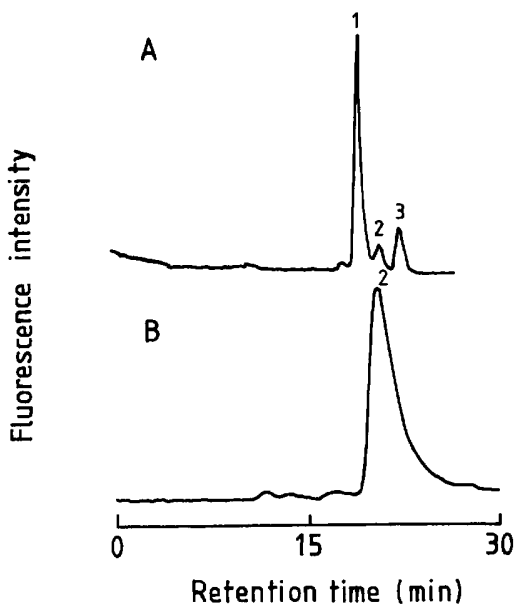

FIG. 1. HPLC chromatogram of TTX and its derivatives. (A) Extract from strain JH 122 of $S$. alga; (B) authentic TTX and its derivatives. Peaks: 1, TTX; 2, 4-epi-TTX; 3, anh-TTX.

\section{DISCUSSION}

Since the first report by King on clinical isolates of $S$. putrefaciens (10), the strains were conventionally identified by the following characteristics: nonfermentative, gramnegative, rod shaped, oxidase positive, hydrogen sulfide production. However, heterogeneity of the species was pointed out by many researchers $(2,7,13,14,18,20,21,23$, 24,28 , especially the remarkable differences between clinical and environmental isolates. One of the reasons why taxonomic study of these isolates had not been done was the difficulty in collecting strains from human clinical specimens, because $S$. putrefaciens infections in humans are rare.

We obtained 40 strains individually isolated from human clinical specimens during the period of 1978 to 1991 in Japan. Studies of the characteristics of these strains led us to the findings that 33 of these strains were $\beta$-hemolytic and had apparently higher moles percent $\mathrm{G}+\mathrm{C}$ values than that of the type strain of $S$. putrefaciens. Taxonomic studies on $S$. putrefaciens strains, including the type strain, some IAM strains, and newly isolated clinical and environmental strains, were then performed. The results showed that all clinical strains that have 52 to $54 \mathrm{~mol} \% \mathrm{G}+\mathrm{C}$ belong to $S$. alga, not to $S$. putrefaciens.

The type strain of $S$. alga (IAM $14159^{\mathrm{T}}$ ), which was isolated from red algae is reported to be a TTX-producing marine bacterium $(25,26)$. We showed that four clinical strains identified as $S$. alga in this study produced 4-epi-TTX

TABLE 4. Production of TTX and its derivatives by $S$. alga strains isolated from human clinical specimens

\begin{tabular}{|c|c|c|c|c|c|}
\hline \multirow{2}{*}{ Bacterial strain } & \multirow{2}{*}{ Source } & \multicolumn{3}{|c|}{ Compound detected by HPLC } & \multirow{2}{*}{$\begin{array}{c}\text { Quantitative measurement of TTX } \\
\text { by tissue culture assay } \\
\text { (ng/g of cells) }\end{array}$} \\
\hline & & TTX & 4-epi-TTX ${ }^{a}$ & Anh-TTX & \\
\hline \multirow[t]{2}{*}{ IAM 13615} & Cell extract & - & + & - & $<142$ \\
\hline & Culture medium & + & - & + & 1,302 \\
\hline \multirow[t]{2}{*}{ JH 122} & Cell extract & - & + & - & 335 \\
\hline & Culture medium & + & - & + & $<223$ \\
\hline \multirow[t]{2}{*}{ ТPH 519} & Cell extract & - & + & - & 341 \\
\hline & Culture medium & + & + & + & 341 \\
\hline \multirow[t]{2}{*}{ SH 8764} & Cell extract & - & + & - & 279 \\
\hline & Culture medium & + & - & + & 2,440 \\
\hline
\end{tabular}

\footnotetext{
a 4-epi-TTX and anh-TTX are TTX derivatives with lower lethal toxicities to mice than that of TTX (19).
} 
TABLE 5. Characteristics distinguishing $S$. alga from $S$. putrefaciens $s^{a}$

\begin{tabular}{|c|c|c|c|c|c|c|c|c|}
\hline \multirow{2}{*}{ Species } & \multirow{2}{*}{$\begin{array}{c}\mathrm{G}+\mathrm{C} \text { content } \\
(\mathrm{mol} \%)\end{array}$} & \multirow{2}{*}{$\begin{array}{c}\text { Hemolysis on sheep } \\
\text { blood agar }\end{array}$} & \multicolumn{4}{|c|}{ Growth under condition: } & \multicolumn{2}{|c|}{ Acid produced from: } \\
\hline & & & $6 \% \mathrm{NaCl}$ & $4^{\circ} \mathrm{C}$ & $42^{\circ} \mathrm{C}$ & $\overline{\text { SS agar }}$ & Maltose & L-Arabinose \\
\hline S. alga & $52-54$ & $+(100)$ & $+(100)$ & $-(0)$ & $+(97)$ & $+(88)$ & $-(0)$ & $-(0)$ \\
\hline S. putrefaciens & $45-48$ & $-(0)$ & $-(0)$ & $+(65)$ & $-(0)$ & $-(8)$ & $+(88)$ & $+(100)$ \\
\hline
\end{tabular}

${ }^{a}$ Thirty-six strains of $S$. alga were used, including IAM $14159^{\mathrm{T}}$ (the type strain of $S$. alga), IAM 13614 and IAM 13615 (which were originally classified as $S$. putrefaciens), and 33 clinical strains. Forty-one strains of $S$. putrefaciens were used, including IAM $12079^{\mathrm{T}}$ (the type strain of $S$. putrefaciens), IAM 13595, and seven clinical strains and 32 environmental strains isolated in this study. Values in parentheses are the percentages of positive strains.

and might release TTX or anh-TTX into the culture medium. The results of tissue culture assay which is used for detection of the sodium-channel blocking activity of TTX also support the production of TTX and its derivatives by these strains.

On the basis of 35 strains genetically identified as $S$. alga, we clarified the physiological differences between $S$. alga and $S$. putrefaciens as presented in Table 5. Thus, we propose the emended description of $S$. alga given below.

Emended description of Shewanella alga (Simidu, KitaTsukamoto, Yasumoto, and Yotsu 1990). Cells are gramnegative, straight short rods and have polar flagella. They grow in $6 \% \mathrm{NaCl}$, on Salmonella-Shigella agar, and at $42^{\circ} \mathrm{C}$, but not at $4^{\circ} \mathrm{C}$. Colonies become yellow-orange or brown after 2 days of incubation at $37^{\circ} \mathrm{C}$. Reduction of trimethylamine oxide reaction is positive. All strains produce hydrogen sulfide, indophenol oxidase, ornithine decarboxylase, gelatinase, DNase, lecithinase, and lipase. Acids are produced by oxidation from D-ribose, but not from D-arabinose, L-arabinose, D-mannose, mannitol, iso-inositol, L-rhamnose, $\mathrm{D}$-xylose, sucrose, maltose, and D-lactose. Acid production from $\mathrm{D}$-glucose is variable. They exhibit hemolysis on sheep blood agar and are pathogenic to humans. The $\mathrm{G}+\mathrm{C}$ content of the DNA is 52 to $54 \mathrm{~mol} \%$. Production of tetrodotoxin and its derivatives is confirmed by the type strain (IAM $14159^{\mathrm{T}}$ ) $(25,26)$ and some clinical strains.

The species can be differentiated from $S$. putrefaciens by the following characteristics: growth at $42^{\circ} \mathrm{C}$, in $6 \% \mathrm{NaCl}$, and on Salmonella-Shigella agar, hemolysis on sheep blood agar, acid production from D-ribose but not from L-arabinose.

The type strain is IAM 14159 (OK-1; Simidu et al., 1990).

The moles percent $\mathrm{G}+\mathrm{C}$ of the type strain is 54 (Simidu et al., 1990).

Conclusions. Thus, we reidentified the strains of $S$. putrefaciens which have 52 to $54 \mathrm{~mol} \% \mathrm{G}+\mathrm{C}$ as $S$. alga. However, the question remains as to whether or not $S$. alga belongs to the genus Shewanella, because $S$. alga is the only species in the genus that has a high moles percent $\mathrm{G}+\mathrm{C}$. Analysis of part of the sequence of 16S rRNA of $S$. alga showed that this strain is more closely related to $S$. putrefaciens than to species in the Pseudomonas or Alteromonas genus (26). Comparative study of the full sequence of $16 \mathrm{~S}$ rRNA with other strains in the Shewanella genus is needed to confirm the taxonomic situation of $S$. alga.

At the same time, we found at least three DNA homology groups within the strains which have 45 to $48 \mathrm{~mol} \% \mathrm{G}+\mathrm{C}$. Similar findings for the $S$. putrefaciens strains have been reported by several researchers $(14,20,23,28)$. At present, however, we could not find significant traits to differentiate these homology groups. A new classification of $S$. putrefaciens should be proposed in the near future after significant characteristics distinguishing between the different DNA homology groups are found.

\section{ACKNOWLEDGMENTS}

We are grateful to Hideki Matsumoto and Yoshiyuki Kawakami for helpful discussions and to Yukie Okimura and Hiroyuki Yamamoto for technical advice. We are indebted to the following individuals who kindly provided bacterial strains: Eiko Yabuuchi of Osaka City University, Masakazu Koda of Tokyo Metropolitan Police Hospital, Kazue Saku of Bokutou Metropolitan Hospital, Toyoko Oguri of Juntendo University Hospital, and Yoshiyuki Kawakami of Shinshu University Hospital. We thank David Womble, Center for Molecular Biology, Wayne State University, for reading and correcting the article.

This work is partially supported by grant 03304017 from the Ministry of Education, Science, and Culture of Japan.

\section{REFERENCES}

1. Baumann, L., P. Baumann, M. Mandel, and R. D. Allen. 1972. Taxonomy of aerobic marine eubacteria. J. Bacteriol. 110:402429.

2. Baumann, P., M. J. Gauthier, and L. Baumann. 1984. Genus Alteromonas Baumann, Baumann, Mandel and Allen 1972, $418^{\text {AL }}$, p. 343-352. In N. R. Krieg and J. G. Holt (ed.), Bergey's manual of systematic bacteriology, vol. 1. Williams \& Wilkins Co., Baltimore.

3. Debois, J., H. Degreef, J. Vandepitte, and J. Spaepen. 1975. Pseudomonas putrefaciens as a cause of infection in human. $J$. Clin. Pathol. 28:993-996.

4. Derby, H. A., and B. W. Hammer. 1931. Bacteriology of butter. IV. Bacteriological studies on surface tainted butter. Iowa Agric. Exp. Stn. Res. Bull. 145:289-416.

5. Ezaki, T., Y. Hashimoto, and E. Yabuuchi. 1989. Fluorometric deoxyribonucleic acid-deoxyribonucleic acid hybridization in microdilution wells as an alternative to membrane filter hybridization in which radioisotopes are used to determine genetic relatedness among bacterial strains. Int. J. Syst. Bacteriol. 39:224-229.

6. Gilardi, G. L. 1972. Infrequently encountered Pseudomonas species causing infection in humans. Ann. Intern. Med. 77:211215.

7. Gilardi, G. L. 1985. Pseudomonas, p. 350-372. In E. H. Lennette, A. Balows, W. J. Hausler, Jr., and H. J. Shadomy (ed.), Manual of clinical microbiology, 4th ed. American Society for Microbiology, Washington, D.C.

8. Heimbrook, M. E., W. L. L. Wang, and G. Campbell. 1989. Staining bacterial flagella easily. J. Clin. Microbiol. 27:26122615.

9. Holmes, B., S. P. Lapage, and H. Malnick. 1975. Strains of Pseudomonas putrefaciens from clinical material. J. Clin. Pathol. 28:149-155.

10. King, E. O. 1964. The identification of unusual pathogenic gram-negative bacteria. National Communicable Disease Center, Atlanta.

11. Kogure, K., M. L. Tamplin, U. Simidu, and R. R. Colwell. 1988. A tissue culture assay for tetrodotoxin, saxitoxin and related toxins. Toxicon 26:191-197.

12. Laycock, R. A., and L. W. Reiger. 1971. Trimethylamineproducing bacteria on haddock (Melanogrammus aeglefinus) fillets during refrigerated storage. J. Fish. Res. Board Can. 28:305-309.

13. Lee, J. V., D. M. Gibson, and J. M. Shewan. 1977. A numerical 
taxonomic study of some Pseudomonas-like marine bacteria. J. Gen. Microbiol. 98:439-451.

14. Levin, R. E. 1972. Correlation of DNA base composition and metabolism of Pseudomonas putrefaciens isolates from food, human clinical specimens, and other sources. Antonie Leuwenhoek 38:121-127.

15. Levin, R. E. 1975. Characteristics of weak $\mathrm{H}_{2} \mathrm{~S}$-producing isolates of Pseudomonas putrefaciens from human infection. Antonie Leeuwenhoek 41:569-574.

16. Long, H. F., and B. W. Hammer. 1941. Classification of organisms important in dairy products. III. Pseudomonas putre faciens. Iowa Agric. Exp. Stn. Res. Bull. 285:176-195.

17. MacDonell, M. T., and R. R. Colwell. 1985. Phylogeny of the Vibrionaceae, and recommendation for two new genera, Listonella and Shewanella. Syst. Appl. Microbiol. 6:171-182.

18. Molin, G., and A. Ternström. 1986. Phenotypically based taxonomy of psychrotrophic Pseudomonas isolated from spoiled meat, water, and soil. Int. J. Syst. Bacteriol. 36:257-274.

19. Nakamura, M., and T. Yasumoto. 1985. Tetrodotoxin derivatives in puffer fish. Toxicon 23:271-276.

20. Owen, R. J., R. M. Legros, and S. P. Lapage. 1978. Base composition, size and sequence similarities of genome deoxyribonucleic acids from clinical isolates of Pseudomonas putrefaciens. J. Gen. Microbiol. 104:127-138.

21. Riley, P. S., H. W. Tatum, and R. E. Weaver. 1972. Pseudomonas putrefaciens isolates from clinical specimens. Appl. Microbiol. 24:798-800.

22. Rosenthal, S. L., J. H. Zuger, and E. Apollo. 1975. Respiratory colonization with Pseudomonas putrefaciens after near-drowning in salt water. Am. J. Clin. Pathol. 64:382-384.
23. Semple, K. M., L. D. James, and D. W. S. Westlake. 1989. DNA relatedness of oil-field isolates of Shewanella putrefaciens. Can. J. Microbiol. 35:925-931.

24. Semple, K. M., and D. W. S. Westlake. 1987. Characterization of iron-reducing Alteromonas putrefaciens strains from oil field fluids. Can. J. Microbiol. 33:366-371.

25. Simidu, U., K. Kita-Tsukamoto, T. Yasumoto, and M. Yotsu. 1990. Taxonomy of four marine bacterial strains that produce tetrodotoxin. Int. J. Syst. Bacteriol. 40:331-336.

26. Simidu, U., T. Noguchi, D.-F. Hwang, Y. Shida, and K. Hashimoto. 1987. Marine bacteria which produce tetrodotoxin. Appl. Environ. Microbiol. 53:1714-1715.

27. Smibert, R. M., and N. R. Krieg. 1981. General characterization, p. 409-443. In P. Gerhardt, R. G. E. Murray, R. N. Costilow, E. W. Nester, W. A. Wood, N. R. Krieg, and G. B. Phillips (ed.), Manual of methods for general bacteriology. American Society for Microbiology, Washington, D.C.

28. Stenstrom, I.-M., and G. Molin. 1990. Classification of the spoilage flora of fish, with special reference to Shewanella putrefaciens. J. Appl. Bacteriol. 68:601-618.

29. von Graevenitz, A., and G. Simon. 1970. Potentially pathogenic, nonfermentative, $\mathrm{H}_{2} \mathrm{~S}$-producing gram-negative rod (1 b). Appl. Microbiol. 19:176.

30. Wood, A. J., and E. A. Baird. 1943. Reduction of trimethylamine oxide by bacteria. 1. The enterobacteriaceae. J. Fish. Res. Board Can. 6:194-201.

31. Yasumoto, T., and T. Michishita. 1985. Fluorometric determination of tetrodotoxin by high performance liquid chromatography. Agric. Biol. Chem. 49:3077-3080. 